\title{
Building Enforcement Capacity for Brazilian Corporate and Securities Law
}

\author{
John Armour ${ }^{*}$ and Caroline Schmidt ${ }^{* *}$
}

\begin{abstract}
Brazil is one of the world's largest emerging markets, with many opportunities for development. Persuading financiers to commit funds to Brazilian firms requires effective corporate and securities laws to facilitate 'arm's length' contracting. Enforcement of these laws is problematic. Brazilian judges are over-worked, with a long case backlog. They lack relevant business expertise, and are often expected to anticipate 'social and economic consequences' in their judgments. This provides little certainty. Nevertheless, authorities and market participants have developed an array of specialist enforcement institutions, which build upward from the authority of the inefficient courts, and overlap each other. Drawing on qualitative data from interviews with participants, we document the evolution and interaction of four such institutions in Brazilian corporate and securities law: (i) The growing role of arbitration; (ii) the restructuring of the São Paulo Court of Justice to create specialist panels of expert commercial judges; (iii) a dedicated administrative court operated by the Brazilian securities regulator (the ' $C V M$ '); and (iv) a recent initiative to create a Brazilian Takeover Panel (the 'CAF'). Together they form a mutually reinforcing system of enforcement, the sum of which is far greater than its unpromising judicial foundations.
\end{abstract}

\footnotetext{
* Hogan Lovells Professor of Law and Finance, Oxford University; Research Fellow, European Corporate Governance Institute.

** Research Fellow in Law and Finance, Oxford University.

This research was funded by an ESRC Grant under the Rising Powers and Interdependent Futures initiative. We are grateful to those we interviewed in the course of conducting this research.
} 


\section{Introduction}

In this article, we study the development of enforcement institutions for Brazilian corporate and securities law. In common with many other emerging markets, Brazilian equity markets channel only a relatively modest proportion of funding into public firms. Persuading financiers to commit funds on an arm's-length basis to public companies requires effective corporate and securities laws and associated institutions. This implies both appropriate rules and effective enforcement institutions. Brazilian policymakers and regulators have sought, over the past 15 years, to improve the quality of the corporate governance and securities rules protecting outside investors in such companies. However, it is well-established in the literature that the quality of enforcement institutions are at least as important as the substantive law in facilitating investment.

A central challenge for Brazil, however, concerns the limitations of the regular courts as forums for adjudicating complex business law disputes. They are slow to decide cases, and the judges lack relevant business expertise. Moreover, they are uncertain as regards outcomes, and do not produce clear guidance for parties to plan their affairs without recourse to litigation. These limitations create two linked problems for corporate law: a lack of certainty ex ante, because of the discretionary nature of much decision-making and the lack of expertise of judges, and a delay in getting a decision ex post.

In this paper we document four strategies employed by Brazilian actors to improve adjudication institutions for corporate law. These can be pursued independently, but in a way that overlaps, such that they mutually reinforce each others' efficacy. Our research draws on data collected through interviews with Brazilian lawyers and market participants. ${ }^{1}$

First, there has been a vast growth in the use of arbitration to resolve commercial disputes generally in Brazil. This bypasse the ordinary court system to some degree, giving parties access to expert dispute resolution rapidly. Second, the São Paulo Court of Appeal (Tribunal de Justiça de São Paulo) was restructured in 2010 to create a specialist panel of expert business law judges. Third, the Brazilian Securities and Exchanges Commission (Comissão de Valores Mobiliários or 'CVM'), operates a dedicated 'administrative' court, with power to enforce CVM regulations and public company law. Fourth, a recent initiative seeks to create a new player: the Mergers and Acquisitions Committee (Comitê de Aquisições e Fusões or ' $\left(\mathrm{AFF}^{\prime}\right.$ ), intended to provide a decision-making body for M\&A transactions.

The weakness of legal institutions in supporting finance is a problem shared by most emerging markets and indeed many developed markets. An appreciation of the Brazilian experience in overcoming these problems may therefore yield insights to policymakers elsewhere.

The remainder of this paper is structured as follows. Section 2 reviews the literature on law and finance highlighting the importance of effective institutions, especially as regards

\footnotetext{
${ }^{1}$ We conducted thirty-eight semi-structured and open-ended interviews with professional subjects connected to law and finance in Brazil, including legal practitioners, judges, arbitrators, investment bankers, in-house lawyers, regulators, and officials at the Brazilian development bank (BNDES). Interviews were conducted in London, Brasilia, Rio de Janeiro and São Paulo. Interviews were held in English and Brazilian Portuguese, in person and without liaison. They were typically around 1.5 hours in length, and recorded upon request, followed by note taking. Interviews were held with Brazilian nationals, selected through purposeful snowball sampling, where interviewees recommended their peers based on their judgments about individuals' levels of expertise and reputation - leading to a sample that includes many key actors. Subjects were sent an aide memoire containing a series of questions in advance, and the interviews began with this agenda but were allowed to develop in line with the interests of the subjects. Confidentiality was secured as requested.
} 
enforcement, for the growth and development of arm's-length finance. Section 3 presents background on the Brazilian context: the economy and capital markets, and the challenges faced by judicial infrastructure. Section 4 describes the four mechanisms used to build enforcement capacity, in Brazilian corporate and securities laws, and Section 5 discusses the extent to which the findings are capable of generalization to other countries.

\section{Law and finance: The importance of institutions}

A large body of literature has explored the links between legal institutions and the raising of finance. As a matter of theory, legal institutions matter because they facilitate arm's-length contracting. Suppliers of capital fear opportunistic behaviour by those controlling the firm. Once finance has been raised, controllers may divert resources to themselves, at the expense of the investors, a practice sometimes referred to as 'tunnelling'. ${ }^{2}$ In theory, legal protection for minority shareholders can reduce the extent to which such expropriation takes place. Of course, expropriation might be constrained even in the absence of credible legal enforcement, because of a controller's concern about their reputation. However, establishing a reputation takes time, creating a barrier to entry. Effective legal institutions, by enabling financiers to enforce arm's length contracts-that is, not relying on reputation or prior dealings - can help firms to raise finance more easily.

An influential body of empirical literature has explored links between legal protection offered to investors and the raising of finance. Seminal contributions from La Porta, Lopesde-Silanes, Shleifer and Vishny reported a correlation between legal protection of outside investors, as measured by an index of 'quality of law', and the depth and liquidity of stock markets. ${ }^{3}$ While the particular construction of the initial index has been subject to criticism, ${ }^{4}$ the methodological innovation has spawned a new literature. A subsequent refinement focuses on situations of self-dealing, precisely the type of issue that will occur between controlling shareholders and a minority. ${ }^{5}$

Of course, not all transactions between controlling shareholders and their firms are harmful for minority shareholders. Consequently, many jurisdictions regulate self-dealing by specifying a procedure through which approval may be granted: whether by minority shareholders, independent directors, or even a court. Direct court decision-making makes heavy demands on the judiciary. Minority shareholders must be able to launch a petition for judicial scrutiny cheaply, and courts must be able to review the transaction quickly. The court must be free from actual or apparent bias, and the judge must have sufficient business knowledge to be able to make sense of relevant expert evidence.

\footnotetext{
2 See eg, S Johnson, R La Porta, F Lopez-de-Silanes and A Shleifer, 'Tunneling' (2000) 90 American Economic Review 22; V Atanasov, B Black and CS Ciccotello, 'Law and Tunneling' (2011) 37 Journal of Corporation Law 1.

${ }^{3}$ R La Porta, F Lopez-de-Silanes, A Sheifer and RW Vishny, 'Legal Determinants of External Finance' (1997) 52 Journal of Finance 1131. See also, for a more recent survey, R La Porta, F Lopez-de-Silanes and A Shleifer, 'The Economic Consequences of Legal Origins' (2008) 46 Journal of Economic Perspectives 285.

${ }^{4}$ See eg J Armour, S Deakin, P Sarkar, M Siems and A Singh, 'Shareholder Protection and Stock Market Development: An Empirical test of the Legal Origins Hypothesis' (2009) 6 Journal of Empirical Legal Studies 343; H Spamann, 'The “Antidirector Rights" Index Revisited' (2010) 23 Review of Financial Studies 467.

${ }^{5}$ S Djankov, R La Porta, F Lopez-de-Silanes and A Shleifer, 'The Law and Economics of Self-Dealing' (2008) 88 Journal of Financial Economics 430. However, cf DM Klerman, PG Mahoney, H Spamann and MI Weinstein, 'Legal Origin or Colonial History?' (2011) 3 Journal of Legal Analysis 379.
} 
In the presence of limitations on courts' ability to meet these challenges, delegation of review of self-dealing transactions to independent directors and/or shareholders may seem attractive. However, this creates additional pressure. Independent directors must in fact be independent. And for shareholder voting to work, the vote must be free from coercion, and shareholders secure in the belief that a vote against the controller will not result in some form of retaliation. Each of these mechanisms consequently requires some second-order judicial support-reviewing the appointment of supposedly independent directors, and/or the conduct of shareholder votes. If courts cannot supply such support, then these mechanisms will not function effectively.

\section{The Brazilian Context}

\subsection{Economy and Finance}

Brazil is the world's seventh largest economy by GDP. It experienced rapid growth in the early twenty-first century, peaking at 7.5 per cent in $2010 .{ }^{6}$ In common with many emerging markets, Brazil's capital markets represent only a modest portion of GDP, with finance for industry being sourced largely from retained earnings or from the state in the form of loans from the Brazilian Development Bank ('BNDES'). ${ }^{7}$

From the mid-1960s until 1985, Brazil was ruled by a military regime. Hyperinflation was endemic from the early 1970s, with annualised rates peaking at over 1,000 per cent in the early 1990s. During this time, capital markets languished. A key component of successive authoritarian governments' strategy for maintaining public order was to guarantee that household savings would not be dissipated by inflation, achieved through indexation of savings accounts. A by-product, however, was to crowd out investment in industry: given an attractive risk-free real rate of interest on savings accounts, domestic investors were not interested in equities, still less corporate bonds. At the same time, capital controls choked off foreign investment. The combined result was that Brazilian businesses had little access to private capital. Consistently with this picture, most significant businesses were state-owned and much of the debt finance was channelled through BNDES.

Following Brazil's return to democracy in 1985, successive governments tried a variety of measures to bring inflation under control, which succeeded in gaining traction only by the mid-1990s. At around this time, Brazil embarked on a massive privatization programme. ${ }^{8}$ This coincided with the opening of the economy internationally, triggering an influx of foreign portfolio investment.

The next decade saw substantial progress in the development of Brazilian capital markets. This has been associated with the introduction by the Brazilian Stock Exchange (Bovespa) in 2000 of the Novo Mercado ('New Market') listing segment, with higher associated corporate governance standards. ${ }^{9}$ From 2004 to 2008, the Brazilian Stock Market

\footnotetext{
${ }^{6}$ Source: Instituto Brasileiro de Pesquisa Econômica Aplicada (data available at www.ipeadata.gov.br).

${ }^{7}$ MH Santana, M Ararat, P Alexandru, B Yurtoglu and M Rodrigues da Cunha, 'Novo Mercado and Its Followers: Case Studies in Corporate Governance Reform', IFC/Global Corporate Governance Forum Focus 5 (2008), 2.

${ }^{8} \mathrm{~F}$ Anuatti-Neto, M Barossi-Filho, AG de Carvalho and R Macedo, 'Costs and Benefits of Privatization: Evidence from Brazil', Inter-American Development Bank Research Network WP No R-455 (2003).

${ }^{9}$ See eg E Gorga, 'Changing the Paradigm of Stock Ownership from Concentrated towards Dispersed Ownership: Evidence from Brazil and Consequences for Emerging Countries' (2009) 29 Northwestern Journal of International Law \& Business 439; BS Black, AG de Carvalho and E Gorga, 'Corporate Governance in Brazil' (2010) 11 Emerging Markets Review 21; BS Black, AG de Carvalho and E Gorga, 'What Matters and for Which Firms for Corporate
} 
experienced unprecedented growth. During this period, 113 companies filled IPOs with the Brazilian Securities and Exchange Commission (that is, the CVM). ${ }^{10}$ The average daily trading volume on Bovespa increased from BR\$1.2bn in 2004 to BR\$5.5bn in 2008. Stock market capitalization deepened enormously, growing from 35 per cent of GDP in 2000 to 100 per cent by 2007. There are currently 525 public companies listed on Bovespa, but the ratio of their market capitalization to GDP tailed off somewhat from the high point of 2007, falling to 55 per cent in $2012 .^{11}$

\subsection{Law enforcement: the problem of judicial backlogs}

Brazilian courts present a bottleneck to litigants. There is a huge backlog in judicial caseloads. Our interviewees recounted that lawsuits could take 10 or more years until a final trial. ${ }^{12}$ They viewed the large backlog of cases as in part a function of the litigation rate, and in part a function of courts' difficulties in closing cases. Others spoke of the use of litigation, at least after the return to democracy, as a means of challenging overreaching measures in fields such as taxation. Consideration of litigation statistics allows us to tell a more nuanced story.

In 2012, Brazil's annual litigation rate was 12.8 new suits were filed per 100 citizens. ${ }^{13}$ This is high, but not exceptionally large by international comparison: the average across the EU in 2010 was $11.3,{ }^{14}$ and for the US the equivalent number was $5.8 .{ }^{15}$ Much of the litigation in Brazil is between the business sector and the state, with tax foreclosure proceedings accounting for 32 per cent of all cases. ${ }^{16}$ Data from 2011 disclose that federal public bodies were the most frequent litigants, plaintiffs in 12 per cent of new cases filed that year, followed by the financial sector (11 per cent), municipal authorities (seven per cent) and other state public bodies (four per cent). ${ }^{17}$ When tax and employment cases are removed from the picture, the total level of litigation appears much more modest. Together, this suggests that the high backlog is not primarily a function of 'litigiousness' of Brazilians.

Governance in Emerging Markets? Evidence from Brazil (and Other BRIK Countries)' (2012) 18 Journal of Corporate Finance 934.

10 BM\&FBovespa, Public Offerings and IPOs (www.bmfbovespa.com.br/pt-br/mercados/acoes/ofertaspublicas/ofertas-publicas.aspx?idioma=pt-br).

${ }^{11}$ World Bank, World Development Indicators 2013, Table 5.4 (wdi.worldbank.org/table/5.4).

${ }^{12}$ One spoke vividly of a matter in which his law firm was acting between corporate parties, in relation to which none of the natural persons originally involved was still alive, making it very hard to determine what had happened.

13 See Conselho Nacional de Justiça ('CNJ'), Executive Summary: Courts in Figures 2013 - The Base Year 2012 (Brasilia: CNJ, 2013), 9 (filing data); World Bank, World Development Indicators 2013, Table 2.1 (wdi.worldbank.org/table/2.1).

${ }^{14}$ CEPEJ (European Commission for the Efficiency of Justice), The Functioning of Judicial Systems and the Situation of the Economy in the European Union Member States, Report prepared for the European Commission (DG Justice), January 2013, 629 (Table 5). A number of EU countries have significantly higher rates of case filing than Brazil, including Austria, Denmark, Germany, Poland and Slovenia.

15 JM Ramseyer and EB Rasmusen, 'Comparative Litigation Rates', Harvard John M. Olin Center for Law, Economics \& Business Discussion Paper No 681 (2010), 5 (Table 1).

16 CNJ, above $n 13,13$. These have a particularly high non-completion rate, with only 11 tax foreclosure cases out of 100 annually remanded or dismissed: ibid., 9.

${ }^{17}$ CNJ, 100 Maiores Litigantes (Brasília: CNJ, 2012), 8. 
Where Brazil stands out internationally is in its backlog of pending cases. Countries with high litigation rates generally have court systems that are able to manage the caseload, resulting in only modest backlogs carried across from year to year. That is not the case in Brazil, which in 2012 had an astonishing 29.3 lawsuits pending per 100 citizens, ${ }^{18}$ nearly seven times higher than the EU-wide average of 4.4. ${ }^{19}$ The high backlog relative to the litigation rate suggests that courts have difficulties in completing cases. ${ }^{20}$

The source of this difficulty does not seem to be lack of judicial resources. Brazilian judges are well-paid, with typical salaries similar in absolute terms to judicial pay in Germany, and equivalent to 32 times average annual salaries in Brazil. ${ }^{21}$ Moreover, Brazil has 8.8 judges per 100,000 citizens, ${ }^{22}$ significantly more than the UK (3.6) and nearly as many as the US (10.8). ${ }^{23}$ Although it is less than half the average in the EU (18.9), ${ }^{24}$ the difference is nowhere near as large as the sevenfold difference in pendency. The large number of well-paid judges means that Brazil's expenditure on the judicial branch accounts for 3.2 per cent of total public expenditure, ${ }^{25}$ far more, for example, than the average of 0.44 per cent across the EU. ${ }^{26}$ Both quantity and-by inference from salary-quality of the Brazilian judiciary are comparatively high.

One might imagine that another possible cause could be corruption. If Brazilian judges were not performing their function effectively because of bribery or political influence, this would greatly undermine the efficacy of the legal system. Yet we find this unpersuasive as a complete explanation for the observed pattern of backlog, for two reasons. First, as we have seen, Brazilian judges are well-paid, whether by relative or even absolute standards. This makes corruption much less likely. Second, and consistently with this, Brazil does not fare particularly poorly on cross-national indicators of corruption when in comparison with other emerging economies. For example, the World Bank's indicators suggest that corruption in Brazil is only half that in Russia, less than a quarter of that in India and approximately a seventh of that in China. ${ }^{27}$

Why then do Brazilian courts struggle to close cases? Our interviewees spoke of a procedural law that was considered highly 'ritualistic', so as to permit too many rights of appeal. Plaintiffs were said to pursue all their rights to appeal, facilitated in this regard by low

\footnotetext{
${ }^{18} \mathrm{CNJ}$, above $\mathrm{n} 13$.

${ }^{19}$ CEPEJ, above $\mathrm{n} 14$.

${ }^{20}$ To be sure, the litigation rate likely under-represents demand for litigation, or 'litigiousness', because the long backlog will reduce parties' expectations as to outcomes. Nevertheless, the causal mechanism would still be the difficulties faced by courts in completing cases.

${ }^{21}$ M Dakolias, 'Court Performance around the World: A Comparative Perspective', World Bank Technical Paper No 430 (1999), 21.

${ }^{22} \mathrm{CNJ}$, above $\mathrm{n} 13,7$.

${ }^{23}$ See CEPEJ, above n 14, 631 (UK data: Table 6); Ramseyer and Rasmusen, above n 15, 5 (US data: Table 1).

${ }^{24}$ CEPEJ, above $\mathrm{n} 14$.

${ }^{25} \mathrm{CNJ}$, above $\mathrm{n} 13,5$.

${ }^{26}$ CEPEJ, above $\mathrm{n}$ 14, 631 (Table 6).

27 World Bank, World Development Indicators 2013, Table 5.2 (wdi.worldbank.org/table/5.2) (percentage of firms reporting making informal payments to public officials: Brazil 11\%, China $72 \%$, India 48\%, Russia $20 \%$ ).
} 
court filing fees. ${ }^{28}$ However, this does not explain why parties pursue these options. In most cases it would be cheaper for parties jointly to settle, so there would be a good reason for doing so.

Another problem frequently mentioned by interviewees, namely uncertainty, could provide the explanation. As a matter of theory, uncertainty over the outcome of a judicial decision makes settlement less likely, as parties are less able to estimate how much they give up-in expected value terms-by not electing to pursue their suit to trial. ${ }^{29}$ There are several potentially relevant sources of uncertainty. One is that judicial decisions do not have the force of binding precedents in Brazil. ${ }^{30}$ The absence of precedents, at least in the common law sense, means that prior decisions are not 'coded' so as to enable subsequent parties to arrange their affairs. This in turn makes it harder for parties to anticipate outcomes to litigation.

However, the absence of precedents cannot be the whole story. Brazil's legal system shares this feature with most civil law systems around the world. Moreover, certainty in Brazilian jurisprudence is to some degree enhanced by a form of judicial pronouncement known as a súmula. Súmulas have the function of harmonizing court jurisprudence, and can be described as a series of concise legal pronouncements made by the court, normally one or two line length, about the holding of the court on a particular matter. These are defined once the court has judged similar case laws and has confirmed a position. The Supreme Court has been publishing súmulas since $1964,{ }^{31}$ and most Appellate Courts now do so also. Traditionally their status was simply to summarise rather than oblige subsequent courts to follow them. However, since 2004, the Supreme Court has published what are known as súmulas vinculantes, which are treated as binding on subsequent courts. ${ }^{32}$

A second source of uncertainty, as regards business decisions, comes from the fact that Brazilian judges typically lack expertise in business matters. Brazilian judges are recruited soon after they graduate from law school, through public exams, with purely legal qualifications. The professional experience they develop is solely that gained from adjudicating cases. Brazilian courts traditionally have generalist jurisdiction in relation to a particular geographic region, meaning that the judges do not usually have the opportunity to develop a specialism in business law over the course of their careers. This makes them poorlysituated to pass judgment on complex commercial matters. The majority of our interviewees were in agreement that courts in Brazil lack expertise to appreciate cases involving matters related to business laws or complex business transactions, with leading lawyers and legal professionals speaking more strongly about the judiciary institutional failure to properly address highly complex commercial cases and, therefore, their preference for arbitration. ${ }^{33}$ However, whilst this is a plausible source of uncertainty as regards litigation outcomes, it too

\footnotetext{
${ }^{28}$ This seems similar to observations made in the context of India: see J Armour and P Lele, 'Law, Finance and Politics: The Case of India' (2009) 43 Law \& Society Review 491, 509-11.

29 The theoretical literature is surveyed in Ramseyer and Rasmusen, above $\mathrm{n} 15$.

30 See ibid.

${ }^{31}$ Emenda Regimental, de 28 de Agosto de 1963, published by the Supreme Federal Court.

${ }^{32}$ Constitutional Amendment No 45/2004, Art 103-A.

${ }^{33}$ See also BM Salama and VM Prado, 'Legal Protection of Minority Shareholders of Listed Corporations in Brazil: Brief History, Legal Structure and Empirical Evidence' (2011) 4 Journal of Civil Law Studies 147.
} 
is similar to the position in many civil law countries, where generalist judges recruited directly from law school are the norm. ${ }^{34}$

A third source of uncertainty, which is specific to Brazil, has to do with the way in which courts approach their interpretative functions. In contractual interpretation, judges may take into account the 'social and economic consequences' of their decisions. The Brazilian Civil Code of 2002 unified the Civil Code of 1916, ${ }^{35}$ and the Commercial Code of $1850,{ }^{36}$ incorporating rules on business activity. Among other changes, the 2002 Civil Code provided, in the section on general provisions applicable to contracts, that, 'the freedom to contract should be exercised by reason and within the limits of the social function of the contract.' ${ }^{37}$ This resonates with Article 5(XXIII) of the Brazilian Constitution of 1988, which provides that 'property shall observe its social function'. ${ }^{38}$ The 'social function' of property and contracts so defined brings public law considerations into the adjudication of private contracts and property. It follows that consequences to third parties may be taken into consideration during legal disputes. Brazilian law does not clearly define the limitations of this concept and legal scholars and courts have been developing its interpretation. The broad application to contracts means that decisions are subject to wide-ranging judicial discretion. Our interviewees reported that court decisions based on the notion of the 'social function of contract' tended to interfere with contractual relations in favour of the party who appeared to the court to be the weaker. Consistently with this, a study of the consequences of litigating breaches of contract reported that affected traders and industries subsequently increased the number of explicit warranties in their contracts, presumably seeking to restrict judicial discretion. ${ }^{39}$ Such interference is also reported to be prevalent prevailing in attempts to enforce debts by creditors, in which courts act as champions of borrowers against financial institutions.

\section{Building capacity in the enforcement of Brazilian securities and corporate law}

We turn now to consider a series of institutional developments, which are deployed in Brazil to seek to overcome the limitations of the courts. We apply a simple analytical framework to understand the ways in which institutional arrangements relevant to securities and corporate law are developing in Brazil, and how key actors perceive they operate. This draws from political science the idea of institutional layering, that is, the incorporation of solutions that overcome institutional limitations without eliminating old institutional structures. ${ }^{40}$ Often

\footnotetext{
${ }^{34}$ GK Hadfield, 'The Levers of Legal Design: Institutional Determinants of the Quality of Law' (2008) 36 Journal of Comparative Economics 43.

${ }^{35}$ Código Civil, Lei 3017, de 1 de Janeiro de 1916.

${ }^{36}$ Código Comercial, Lei 556, de 25 de Junho de 1850.

${ }^{37}$ Código Civil, Lei 10.406, de 10 de Janeiro de 2002, Art 421.

${ }^{38}$ Constitution of the Federative Republic of Brazil (1988); See also A de Santos Cunha, 'The Social Function of Property In Brazilian Law' (2011) 80 Fordham Law Review 1171.

${ }^{39}$ CL Rezende and D Zylbersztajn, 'Quebras Contratuais e Dispersão de Sentença' (2011) Revista Direito GV 7.

${ }^{40}$ See eg K Thelen, How Institutions Evolve: The Political Economy of Skills in Germany, Britain, the United States, and Japan (Cambridge: Cambridge University Press, 2004); J van der Heijden, 'Institutional Layering: A Review of the Use of the Concept' (2011) 31 Politics 9.
} 
institutional change can be posed in terms of 'breakdown and replacement': ${ }^{41}$ historical events lead to critical juncture moments where institutional change or reproduction takes place. 'Layering', however, favours a more nuanced analysis to institutional transformation. In such cases, new arrangements induce incremental changes in the old institutional structures leading to institutional advancements or complementarities. This approach traditionally looks at social processes as they unfold over time and in relation to other processes, specially looking to the ways in which adaptation contributes to institutional continuity. ${ }^{42}$ In our study, we look at legal processes and each of the institutional developments in Brazil can be seen as a 'layer', in which new arrangements are created and, based on the foundation of the basic system of corporate law enforced through state courts. Each derives its legality to some extent from the underlying foundations. Yet each offers a way of overcoming some of the limitations of the underlying system. None is able completely to transcend these limitations, and so each is, by itself, an incomplete solution. However, the fact that all four approaches can be pursued simultaneously means that they overlap to a significant degree, especially in relation to areas crucial for facilitating outside investment such as the control of tunnelling by majority shareholders.

\subsection{Arbitration: the Novo Mercado Arbitration Chamber}

Arbitration is widely used by commercial parties in emerging markets as a way of sidestepping long delays in the regular courts. Moreover, it permits the selection of decision-makers with expertise in the field, thereby allowing for decisions of better quality than those offered by generalist judges who may have little knowledge of business practice. However, Brazil had no tradition of arbitration until the passage of the Arbitration Law of $1996 .{ }^{43}$ Before then, arbitration was viewed as an improper delegation of the decision-making authority entrusted to the courts.

\footnotetext{
41 Thelen, above $n$ 40, 52

42 Ibid.

${ }^{43}$ Arbitration Act (Lei de Arbitragem). Lei 9.307, de 23 de Setembro de 1996.
} 
Arbitrators have no coercive powers of their own, instead relying on the ordinary court system for enforcement. Nevertheless, the workload for the courts is greatly reduced, as all the judge need do is enforce the arbitral award. The benefits of arbitration could easily be undermined if courts retained power to review the validity of arbitration clauses, or of decision-making by arbitrators in accordance with them. To minimise the potential for such challenges, the Brazilian Arbitration Act recognises the principle of 'competencecompetence': that is, that arbitration chambers are themselves competent to confirm the extent and scope of their own competence-namely, the validity and interpretation of arbitration clauses. ${ }^{44}$ Moreover, the Act makes clear that, as regards domestic awards, the arbitrator 'is the judge in fact and in right, and his/her award is not subject to appeal or homologation by State Courts'. ${ }^{45}$ Nevertheless, parties to arbitration can still seek precautionary injunctions in state courts, which can be appealed, therefore, holding up the proceedings until a final decision by the court. Our professional interviewees however felt that even in such cases arbitration was preferable to ordinary litigation, because of the arbitrators' superior business expertise.

Arbitration has a particular manifestation in relation to Brazilian securities law. In December 2000, Bovespa (the São Paulo Stock Exchange) launched the Novo Mercado, special listing segment open to publicly traded companies willing to commit to additional standards of corporate governance. For a company to list on the Novo Mercado, it had to adopt governance practices significantly beyond those required by Brazilian corporate law, including rules expanding shareholder rights and enhancing the scope of issuer disclosure. Adherence to the Novo Mercado is achieved through a private agreement between Bovespa, senior managers, controlling shareholders, and the company itself. ${ }^{46}$ The agreement includes a statement of consent and acceptance of personal liability for non-compliance with the relevant rules. ${ }^{47}$

The story of the Novo Mercado is well known in the corporate law literature. ${ }^{48}$ Here, we focus on a feature that has not received much attention: that companies listing on the Novo Mercado must include an arbitration clause in their articles subjecting intra-corporate disputes to the jurisdiction of the Novo Mercado Chamber of Arbitration (Câmara de Arbitratgem do Mercado or 'CAM'). ${ }^{49}$ The CAM was instituted in 2001 as a complementary arrangement for listed companies to settle disputes in the markets managed by Bovespa. The Brazilian Arbitration Act permits parties, if they elect to do so, to adopt rules from a specialized arbitral body. ${ }^{50}$ In addition, a 2001 reform to the Corporations Act made clear that companies were authorized to choose arbitration as a means to solve disputes between shareholders and the corporation, or between majority and minority shareholders. ${ }^{51}$ The

\footnotetext{
44 Ibid., Art 8.

45 Ibid., Art 18.

${ }^{46}$ BM\&FBovespa, Regulamento de Listagem do Novo Mercado: Atualizado em Fevereiro de 2008, Item 2.1.

47 Ibid.

${ }^{48}$ Gorga, above $\mathrm{n} 9$.

${ }^{49}$ Regulamento de Listagem do Novo Mercado, Item 3.1, IV.

${ }^{50}$ Arbitration Act, Art $13 \S 3$.

51 Lei 10.303, de 31 de Outubro de 2001.
} 
Novo Mercado listing agreement requires the submission of all disputes between the company, shareholders, senior managers, fiscal council members and Bovespa to CAM arbitration. ${ }^{52}$

Bovespa's expressed goal in mandating arbitration clauses for Novo Mercado firms was to sidestep the limitations of the general courts. ${ }^{53}$ The CAM is composed of a minimum of 30 arbitrators, ${ }^{54}$ who are appointed by Bovespa's Board of Directors. ${ }^{55}$ Bovespa undertakes only to select persons with unblemished reputations and well-established knowledge of the capital markets, business law, and relevant technical areas necessary for the resolution of the disputes. ${ }^{56}$ By increasing expertise, and reducing the delay associated with dispute resolution, the CAM was intended to reduce investors' perceptions about the risks associated with weaknesses of enforcement in the regular courts. Our interviewees suggested that Bovespa played an important role in ensuring that listed companies understood the advantages of these arbitration clauses.

Arbitration in general-and the CAM in particular-represents the first example of the 'institutional layering' we describe in this paper. The arbitrator has no inherent legal power, save that which is derived from the courts' recognition of his authority. Yet the introduction of the Arbitration Act of 1996 permitted parties largely to opt out of dispute resolution in the ordinary courts, in favour of privately-selected experts. The arbitrator-whose expertise permits a more predictable and better informed decision-provides the substantive direction, which is then fitted into an enforcement framework that relies upon the domestic courts. As such, it lowers the demands on the judiciary and consequently increases the prospect of effective decisions. Because the arbitrator's authority is derived from that of the court, we can view it as 'layered' on top of the court's underlying jurisdiction.

Arbitration is far from a complete solution, however. First, for arbitration to be invoked, there must be an underlying action launched in the ordinary courts. Consequently, CAM can only improve outcomes conditional on litigation being launched. In order to be capable of protecting minority shareholders against self-dealing and other ways of extracting private benefits, it must be straightforward for shareholders to launch suits alleging a breach of duty by controllers. Yet this does not appear to be the case in Brazil. Many of our interviewees emphasised that shareholder litigation was actually a rarity. Correspondingly, CAM has had an average of only 8.5 new cases per year from 2010 to $2013 .{ }^{57}$ Although the number of cases is small, their average value is very high, reaching $R \$ 57 \mathrm{~m}$ per case over this period.

\footnotetext{
52 Regulamento de Listagem do Novo Mercado, Item 2.1 (disputes submitted to arbitration proceedings include matters related to 'enforcement, validity, efficacy, violation and related effects of: a) the provisions in the Corporation Law, Company's articles, b) rules issued by the National Monetary Council, Central Bank of Brazil and the Securities and Exchange Commission of Brazil, c) all other rules governing capital markets in general, and d) the directives in the listings rules, arbitration rules and the Novo Mercado agreement.')

53 Santana et al, above n 7, 16.

${ }^{54}$ Regulamento de Listagem do Novo Mercado, Item 2.2.

55 Ibid., Item 4.3. Appointment is for a term of 5 years, with the possibility of reappointment. The members of the Body of Arbitrators then appoint, for a term of two years, a President and two Vice Presidents for the Arbitration Chamber: Item 2.2.1.

56 Ibid., Item 4.1.

${ }^{57}$ Data provided to the authors by the CAM, for the purposes of this research, in June 2014.
} 
Second, arbitration proceedings are generally confidential. Whilst the Brazilian Arbitration Act does not mandate confidentiality, ${ }^{58}$ it is common for commercial parties to seek it. Parties generally prefer confidentiality so that sensitive details about the claim and/or its resolution are not released to the public. CAM follows this preference, with its internal rules expressly granting confidentiality to parties. ${ }^{59}$ However, an important drawback to confidential decisions is that they do not permit arbitrators' reasoning to be available to guide future parties as to the likely outcome of disputes. Consequently, while confidential arbitration can make proceedings cheaper ex post, and likely improve the quality of decisionmaking, it does little to assist parties in planning their affairs ex ante. There is a concern among legal professionals-echoed by some of our interviewees - that overreliance on confidential arbitration might in the long run make matters even worse, because not only does arbitration not produce precedents, but it may reduce courts' ability to produce new precedents as well, by diverting disputes that might otherwise generate them. In a bid to provide more guidance for future parties regarding decision outcomes, CAM has modified its rules to provide that the arbitration award, the thesis and legal grounds established in the award may be disclosed, regardless of parties' consent, provided that their identities are not disclosed. ${ }^{60}$ However, this provision has not yet been implemented.

\subsection{Specialized Business Chambers in the São Paulo Court of Justice}

The second change we consider is not so much the introduction of an additional institutional layer as a re-ordering within the existing institution of state courts. It consists of the establishment of a specialist business chamber within the regular courts sitting in São Paulo.

In 2005, following the enactment of the new Brazilian Bankruptcy law, the São Paulo Court of Justice approved the creation of a specialized bankruptcy chamber (Câmara Especial de Falências e Recuperações) and two specialized trial courts in bankruptcy law (Varas Especializadas de Falência e Recuperação). The improvement in the institutional arrangement had various rationales. The most obvious, confirmed by our interviewees, was to provide faster and more expert decisions in commercial (insolvency) cases. There was also an institutional objective of influencing the formation of jurisprudence in higher courts in Brazil. At the time, the backlog of cases in the São Paulo Court of Appeal was not allowing faster decisions and important commercial cases in São Paulo were slower to reach higher courts in comparison to other State Courts, thus failing to influence national precedents. São Paulo is the wealthiest state in Brazil, contributing almost 40 per cent of the national GDP. So the institutional understanding was that the significance of the state in the national economic market, associated with its industry and extensive business transactions, required not only a faster response from the state courts, but also a stronger contribution to national precedents based on specialized decisions in commercial cases.

The Bankruptcy Chamber has established a high reputation among legal professionals, and in 2010 the São Paulo Court of Justice extended the initiative to create a general Business Law Chamber (Câmara Reservada de Direito Empresarial). The new general chamber was responsible for deciding cases involving corporate law, matters related to business

\footnotetext{
${ }^{58}$ Arbitration Act, Art 13, §6 (arbitration should be exercised with impartiality, independence, competence, diligence and discretion: emphasis added).

${ }^{59}$ BM\&FBovespa, Internal Rules of the Market Arbitration Chamber, Item 6.1.

60 Ibid., Item 6.3.
} 
transactions, ${ }^{61}$ and industrial property. Later the chambers dealing with bankruptcy and business law were unified into the current arrangement, consisting of two Business Law Chambers (1a e 2a Câmara de Direito Empresarial). Judges are selected for these Chambers based on their expertise in business law. Our legal professional interviewees were of the opinion that these Chambers have contributed to an increase in legal certainty in the State of São Paulo. The Business Law Chambers have now also produced a body of sumulas (summary precedents) that provides a clearer direction to future parties about the position of the Court.

The establishment of specialist business law chambers seems an obviously desirable innovation, given the institutional context of judicial enforcement in Brazil. To the extent that it serves its function of providing quicker and more certain decisions, it may also be expected to reduce to the demand for arbitration. One might ask whether, therefore, there would be any need for further institutional innovations. A partial answer lies in the still-significant limitations of even a specialist business chamber. Such chambers must still apply the constitutional canons of interpretation; they simply do so with a greater background of business expertise. Thus, while they will tend to increase certainty, at least relative to nonspecialist state courts, it is less clear whether they do so by more than could be achieved through other institutional innovations. In the next two subsections, we will consider two further 'institutional layers' governing related party transactions, in parallel with state courts. The agencies concerned each supply-in whole or in part-additional rules, and initiate their own enforcement actions. These are two further dimensions not offered by specialist chambers: specialist rule production ex ante, and subsidization for enforcement activity.

\subsection{Processo Administrativo in the CVM Court}

Brazil's financial system is regulated and supervised by the National Monetary Council (Conselho Monetário Nacional or ' $\mathrm{CMN}$ '), the Brazilian Central Bank (Banco Central do Brasil - Bacen) and the Brazilian Securities and Exchanges Commission (Comissão de Valores Mobiliários or ' $C V M$ '). ${ }^{62}$ The CVM is an independent government agency, linked to the Ministry of Finance but not subordinate to it, and enjoys financial and budgetary autonomy. ${ }^{63}$ The CVM has a general mandate for promoting the development of Brazil's securities market, encompassing securing its efficient operation, protecting market participants against irregular and illegal activities, reducing information asymmetry, and promoting legal enforcement, ${ }^{64}$ by controlling and inspecting publicly-traded corporations. ${ }^{65}$

Importantly for our purposes, the CVM has enforcement powers encompassing the whole of securities and corporate law, as well as its own resolutions and any other law under which it is granted supervisory jurisdiction. ${ }^{66}$ It can consequently address self-dealing transactions constituting breaches of corporate law. In addition, the CVM has supervisory responsibilities in relation to fundamental transactions involving significant risks for minority shareholders-in particular, corporate restructurings. In 1999, the CVM regulated disclosure

\footnotetext{
${ }^{61}$ Specifically those regulated in the Civil Code, Arts 966 to 1195.

${ }^{62}$ Capital Markets Law, Lei 6.385, de 7 de Dezembro de 1976.

63 Ibid., Art 5. This enhances its credibility as a neutral decision-maker in cases involving state-owned firms.

64 Ibid., Arts 4 and 8.

65 Ibid., Art 8, incise V.

66 Ibid., Art 11.
} 
procedures on the selling of control, or consolidation of existing control, of a company. ${ }^{67} \mathrm{~A}$ new regulation in 2000 introduced special procedures, such as disclosure of information, economic use and the accounting treatment of premium and discount, to govern the legal relationship for share substitution for non-controlling shareholders. ${ }^{68}$ Later regulations characterised any restructuring that only benefitted the controlling shareholder as an abuse of power; ${ }^{69}$ also addressing tender offers, ${ }^{70}$ and more recently, takeover bids. ${ }^{71}$

CVM enforcement powers-whether in relation to the CVM's own regulations or the general corporate law-are not exercised in the ordinary courts, but through a specialist tribunal, the CVM Administrative Court. Thus there are two parallel enforcement mechanisms for breaches of corporate law: shareholder class actions, launched in the ordinary courts, which would in an appropriate case result in arbitration proceedings; and CVM proceedings. This two-track process is legally possible because the CVM's jurisdiction is classified as being 'administrative'.

It is worth expanding a little on the notion of administrative proceedings (processo administrativo). In Brazil, institutions under federal administration ${ }^{72}$ have jurisdiction to initiate processo administrativo with a view to controlling their own activities, the protection of the rights of individuals and the performance of the Federal Public Administration. ${ }^{73}$ Institutional activities are embedded in the notion of internal control of the state and public management supervision. ${ }^{74}$ In general terms it also implies that institutions should, in the performance of their duties, follow the principles of legality and efficiency, aiming to promote the public good and respect for individuals' rights.

The CVM has power to investigate, through processo administrativo, illegal acts and inequitable practices of members of publicly-traded companies and other market participants. ${ }^{75}$ Processo administrativo can be initiated by the various supervision departments at the CVM. ${ }^{76}$ The CVM promotes external routine inspections through its

\footnotetext{
${ }^{67}$ CVM Instrução Normativa 299, de 09 de Fevereiro de 1999. Before 1997, Brazilian corporate law required the acquirer of a controlling stake in a public company to make a (mandatory) tender offer for the shares held by minority shareholders, at the same price as that offered to the controlling shareholder. This requirement was removed in a 1997 reform intended to facilitate the privatization process. In a series of subsequent regulations, however, CVM sought to restore the protection of minority shareholders in corporate restructurings.
}

${ }^{68}$ CVM Instrução Normativa 319, de 03 de Dezembro de 1999.

${ }^{69}$ CVM Instrução Normativa 323, de 19 de Janeiro de 2000, Art 1, incise II.

${ }^{70}$ CVM Instrução Normativa 361, de 05 de Março de 2002.

${ }^{71}$ CVM Instrução Normativa 487, de 25 de Novembro de 2010.

72 Institutions directly linked to the central federal, state or municipal governments are said to be under the direct administration of the state. Entities with their own legal personalities but performing state activities, such as state-owned or state-controlled companies, are said to be under the indirect administration of the state.

${ }^{73}$ Processo Admnistrativo no Âmbito da Administração Pública Federal, Lei 9.784, de 29 de Janeiro de 1999, Art 1.

${ }^{74}$ HL Meirelles, DB Aleixo DB and JE Burle Filho, Direito Administrativo Brasileiro (São Paulo: Malheiros Editores, 2014), 759.

${ }^{75}$ Capital Markets Law 1976, Art 9, incise V.

76 These include the Corporate Relations Office (Superintendência de Relações com Empresas or 'SEP'), the Institutional Investors Supervision Office (Superintendência de Relações com Investidores Institucionais or 'SIN'), 
Compliance Inspection and Examination Office (Superitendência de Fiscalização Externa or 'SFI'). The CVM describes its enforcement strategy as following a risk-based supervisory approach (Supervisão Baseada em Riscos or 'SBR'), identifying risks as the product of the expected probability of a participant committing an illegal act and the severity the act's impact on the market. ${ }^{77} \mathrm{~A}$ general feature of processo administrativo is that interested parties can submit petitions, within the relevant institutional jurisdiction, for the opening of proceedings or the clarification of their own legal obligations. Consequently the CVM is willing to launch an administrative inspection following a request by a private party, if there is evidence of irregularity. This permits administrative enforcement by the CVM to function as a (partial) substitute for private enforcement through the ordinary courts.

Administrative proceedings must follow federal rules, principles of law-including due process-and the relevant institution's internal procedural rules. ${ }^{78}$ Following a processo administrativo, the CVM has power to seek the imposition of penalties including warnings, fines and suspensions, ${ }^{79}$ which are payable independently of civil or criminal liability. ${ }^{80}$ The initial decision regarding imposition of a penalty is made by the relevant part of the CVM with oversight of the party under investigation. That party can then appeal to the full Board of Commissioners, ${ }^{81}$ and from their decision to the Council of Appeals of the National Financial System (Conselho de Recursos do Sistema Financeiro Nacional or 'CRSFN'), 82 or the Ministry of Finance, depending on the subject matter. If a CVM investigation concludes that a crime occurred, the Public Attorney Prosecutor's Office is notified, to permit it to file a criminal suit, ${ }^{83}$ which will be heard in the regular courts.

The CVM's Annual Report gives a snapshot of its annual enforcement activity. In 2012, the CVM received more than 35,000 requests for investigations from investors and members of the general public. Detailed analyses were carried out in 900 cases and the department responsible for publicly-traded companies investigated 350 complaints. ${ }^{84}$ From these, SFI launched 238 external inspections, of which just over half ( 54 per cent) related to investment funds. These in turn lead to 84 administrative proceedings being initiated, most of which related to market manipulation and insider trading. Of the cases initiated, 21 were resolved

the Trading and Markets Supervision Office (Superintendência de Relações de Mercado e Intermediários or 'SMI') and the Accounting and Auditing Ruling Office (Superintêndencia de Normas Contábeis e de Auditoria or 'SNC').

77 Comissão de Valores Mobiliários, Relatório Anual 2012 (São Paulo: Comissão de Valores Mobiliários, 2012), 54.

78 Processo Admnistrativo no Âmbito da Administração Pública Federal, Lei 9.784, de 29 de Janeiro de 1999. See also Meirelles et al, above $n 74$.

79 The CVM's enforcement competence is defined in the Capital Markets Law 1976 (as amended by Law 9.457 of 5 May 1997, Decree-Law 3.995 of 31 October 2001 and Law 10.303 of 31 October 2001), Art $10 \S 10$ and Art 9 , incise $V, \S 5$.

${ }^{80}$ Capital Markets Law 1976, Art 9, incise V.

81 Ibid., Art 11, § 12.

82 Ibid., Art 11, incise III, § 4. The CRSFN was created in 1985 under Decreto 91.152, de 15 de Março de 1985. On rights of appeal, see also 'Processos Adminsitrativos Sancionadores', in Mobiliários CdV (ed) Deliberação CVM 538, de 05 de Março de 2008 (Brasília Diário Oficial da União, 2008), art 37.

${ }^{83}$ Capital Markets Law 1976, Art 12.

${ }^{84}$ Comissão de Valores Mobiliários, above n 77, 55. 
through administrative agreements (Termo de Ajustamento de Conduta), 25 were heard by the Board, and ten were resolved at the Supervisory Level. ${ }^{85}$

The CVM Board are both expert in the relevant subject-matter, and-by the standards of Brazilian public agencies-independent of government. ${ }^{86}$ By law, CVM Board members should be experts in the capital markets and have good reputation. ${ }^{87}$ Board members are appointed by the President of Brazil, following their approval by the Federal Senate. The term is for five years, with no reappointment, and appointments are staggered such that a single member is appointed each year. ${ }^{88}$ An important guarantee of independence is that Board members cannot be removed mid-term other than for criminal or administrative misconduct. ${ }^{89}$

Not only do CVM officials possess more specialist expertise than the regular judiciary, but-according to our interviewees-processo administrativo is likely to produce a result far more quickly. As a result, while the overlapping jurisdictions mean parties may have a choice of enforcement channel, our interviewees thought that petitioning for processo administrativo was generally preferred to launching a suit in the state courts. In their view, it would be quicker and more expert than the state courts, and consequently a better route to a decision.

CVM enforcement thus provides a third 'institutional layer' in relation to the enforcement of minority protection. In principle, processo administrativo runs in parallel with the enforcement of private rights of action in the state courts. It does not rely on them for enforcement, but in contrast is an alternative route to enforce the same underlying rights, at least as respects aspects of corporate and securities laws giving rise to private rights of action. Administrative proceedings do not result in compensation of investors, but does serve an important deterrent function for controllers. Consequently it can be used to protect outside investors from harmful related party transactions. The public funding of CVM, and its control of proceedings, assists private investors by overcoming the costs of launching litigation.

CVM decisions and the state courts do not so much function as substitutes (as with courts and arbitration) but rather as complements. This is because the CVM's administrative jurisdiction and state court civil (or criminal) jurisdiction are not mutually exclusive. After an administrative decision by the CVM, the parties may still bring the case to the regular state courts. Although the CVM Board publish written decisions, technically speaking, their legal consequences are limited to administrative proceedings and only a court decision renders a matter res judicata for civil proceedings. ${ }^{90}$ Yet because processo administrativo moves more quickly than civil litigation, and the CVM Board have specialist expertise, state courts treat CVM decisions as highly influential. ${ }^{91}$ This means that parties generally can look for guidance

\footnotetext{
85 Ibid., 64.

${ }^{86}$ See above $\mathrm{n} 63$ and text thereto.

87 Capital Markets Law 1976, Art 6.

88 Ibid., Art 6, § 1.

${ }^{89} \mathrm{lbid}$., Art 6, $\S 2$. Such misconduct could comprise administrative improbity or non-observance of their duties or other prohibitions associated with their positions: Art 6, § 3 .

90 See Meirelles et al, above $n$ 74, 772.

${ }^{91}$ Moreover, the CVM often plays a role of amicus curiae in securities cases in state courts: see Capital Markets Law 1976, Art 31.
} 
on corporate and securities law to the growing stock of CVM written precedents. Moreover, the expertise of the personnel involved means that the precedents thereby produced-and the guidance to parties they convey-are likely to be of higher average quality than state court decisions.

\subsection{CAF: The Brazilian Takeover Panel}

A fourth 'institutional layer' in enforcement may come to be constituted by Brazil's newlyestablished Mergers and Acquisitions Committee (Comitê de Aquisições e Fusões or 'CAF'). The CAF, which formally began operations in January 2014, is a self-regulatory initiative aimed at securing equitable treatment for shareholders of publicly-traded companies during tender offers (ofertas públicas de aquisição de ações or 'OPAs') and corporate restructuring transactions (operações de reorganização societária)..$^{92}$ Although the CAF does not have any statutory basis, its founders - which include the CVM, Bovespa, the Brazilian Financial Market Association (Associação Brasileira de Entidades dos Mercados Financeiro e de Capital or 'ANBIMA'), the Brazilian Institute of Corporate Governance (Instituto Brasileiro de Governança Corporativa or 'IBGC') and the Association of Capital Markets Investors (Associação de Investidores no Mercado de Capitais or 'AMEC')-hope that it will come to be highly influential in relation to CVM and state court decision-making. ${ }^{93}$

The CAF's regulatory and institutional function is intended to complement those of the CVM. The CAF's Self-Regulatory Code on Mergers and Acquisitions (the 'CAF Code') sets out a series of rules and principles for mergers and acquisitions, which are expressly described as cumulative with, rather than substituting for, applicable legal provisions, including Brazilian corporate and securities law. Similarly, the CAF's activities are expressed not to substitute for the role of CVM administrative oversight in these transactions. ${ }^{94}$ The CAF and its Code, respectively, bring procedural and substantive additions to the pre-existing protections for shareholders.

As far as substance is concerned, the CAF Code applies a 'principles-based' approach in relation to takeovers and corporate restructurings. Key principles include the equal treatment of shareholders, ${ }^{95}$ and the provision of sufficient information for shareholders to make decisions. ${ }^{96}$ There are two main innovations in the CAF Code that go beyond the underlying legal requirements, as regards the protection of minority shareholders. First, it introduces a requirement for a mandatory tender offer whenever an acquiror makes a

\footnotetext{
${ }^{92}$ Comitê de Aquisições e Fusões, The Self-Regulatory Code on Mergers and Acquisitions (2014) (the 'CAF Code'), Preamble 1, I.

${ }^{93}$ Discussions leading to the establishment of the CAF were first initiated by the CVM, and later continued by the São Paulo Stock Exchange (BM\&Bovespa). The Brazilian Association of Publicly-Held Corporations (Associção Brasileira das Companhias Abertas or 'ABRASCA') was also initially involved but subsequently withdrew participation.

${ }^{94}$ CAF Code, Preamble 1, II.

95 Ibid. Art 29, incise I.

96 Ibid., Art 29, incise III (provision of information); incise VIII and IX (consistent and conflict-free provision of information in valuation reports). Another stated principle is that shareholders should make decisions about takeovers or restructurings (incise II). However, this does little to protect minority shareholders as it is satisfied by majority decision-making.
} 
purchase taking their stake above a threshold of the voting stock of the target company. ${ }^{97}$ This is understood as a way of protecting minority shareholders against tunnelling by controllers, because the controller must offer the same price in the mandatory bid to minority shareholders as they have paid to acquire their controlling stake. This gives minority shareholders an option to exit following a change in control, if they are concerned that the acquirer is going to engage in tunnelling. ${ }^{98}$

The second innovation is to give minority shareholders the opportunity to demand a second valuation opinion on restructuring transactions involving related parties, most notably 'freezeout' transactions by a controlling shareholder. ${ }^{99}$ Once the first valuation is released, the companies involved should convene special meetings of the non-controlling ('outstanding') shareholders at which the non-controlling shareholders decide whether they would like to call for a second valuation. ${ }^{100}$ The regular shareholder meetings that would decide on the corporate restructuring itself are not to be called until procedures regarding the valuation have been completed. ${ }^{101}$

Turning to process, the CAF introduces a new decision-making and enforcement agency, the CAF Takeover Panel. The Panel's operation is to some degree modelled on the UK's Takeover Panel. ${ }^{102}$ Thus it operates in 'real time' during a restructuring or takeover to provide the parties with guidance as to appropriate actions. The Panel also offers prior consultations to parties contemplating relevant transactions. ${ }^{103}$. The CAF's Chief Executive is a well-known M\&A practitioner from an investment bank, with many years of experience, and members of the Panel, which will adjudicate disputes, consist of expert arbitrators. Thus what is envisaged is a decision that will be produced ex ante, involving as much input as possible from minority shareholders through the voting rules, and moderated by experts with credibility in the market.

As the CAF has no statutory basis, its decisions cannot be directly enforced other than through reputational sanctions, such as public censure, ${ }^{104}$ or in more extreme cases, withdrawal of the CAF's oversight. However, the CVM offers an important indirect channel of

\footnotetext{
${ }^{97} \mathrm{lbid}$., Arts 65-70. The threshold level, in the range of 20-30 per cent, is set in the articles of a company adhering to the CAF Code. On the history of mandatory tender offers in Brazil, see above $n 67$.

${ }^{98}$ However, there is an exemption for cases where control is already in the hands of a person holding more than 50 per cent of the voting rights: ibid, Art 65, para 5.

99 Ibid., Sections II to V.

$100 \mathrm{lbid}$. Art 84. A special procedure should follow if the special meeting decides to require a second valuation report (Art 85). If the second valuation is more favourable to holders of outstanding shares of the adherent companies or the other way around, but as long the exchange ratios do not differ more than $10 \%$, parties can proceed to revise the share exchange ratio, provided that the no share exchange implemented is not lower than the average between the two valuations.

101 lbid., Art 84, §2. At that meeting, shareholders can approve the transaction or request a third valuation of the companies involved (Art 85, §5) and a final decision should consider the average among the three valuations (Art 88, §IX).

102 See The Takeover Panel, 'About the Panel' (www.thetakeoverpanel.org.uk/structure). On the history of the UK Takeover Panel, see J Armour and DA Skeel, Jr, 'Who Write the Rules for Hostile Takeovers, and Why? -The Peculiar Divergence of U.S. and U.K. Takeover Regulation' (2007) 95 Georgetown Law Journal 1727, 1756-64.

103 Comite de Aquisições e Fusões, Directive Release 2014/001 (2014), Item 24.

${ }^{104}$ CAF Code, Art 136, incise II.
} 
enforcement. The CVM has entered into Cooperation Agreement with the CAF whereby it provides that related party corporate reorganizations undertaken in accordance with the CAF Code will attract a presumption of regularity in administrative proceedings. ${ }^{105}$ Moreover, for companies that opt into the CAF Code by changing their articles, breach of the Code would be a breach of their articles, which could be enforced by the CAF. ${ }^{106}$

The CAF's innovations are only applicable to companies that have elected to submit to its jurisdiction. Such election may take one of two forms. The first is corporate election, where the company through its articles commits to abide by the CAF Code, and the second is a transactional election, whereby the parties to a particular transaction agree to submit the process to the CAF's jurisdiction. Our interviewees were positive about the CAF initiative but explained that companies are resistant to include provisions on their articles. Amending a company's articles to incorporate the Code would benefit the company's minority shareholders were it to be a target but might cost them more were it to be an acquirer. Moreover, it likely would not benefit the controlling shareholder if the company is a target, as they would need to share any control premium with minority shareholders. Consequently most Brazilian companies might be expected to eschew such amendments of their articles: indeed so far, only one company has done so. In the case of a transactional agreement, submitting to the CAF's jurisdiction may be in the interests of both sides in an arm's-length transaction, as it will bring greater expertise and speed to the resolution of disputes. For related party transactions, the primary incentive would seem to be to benefit from the CVM's presumption of regularity.

The CAF is an ambitious attempt to create a new institutional layer for control transactions, which has significant implications for minority investors. Staffed by experts, and making public its decisions, the CAF has the potential to become a source of information for parties wishing to order their affairs in relation to control transactions and restructurings. At least at this early stage of its inception, it is clearly layered on top of the legal authority of the CVM. If it comes to function as conceived, it will represent a sort of outsourcing of decisionmaking and rule-writing authority by the CVM that bears some resemblance to the way in which arbitration functions in relation to state courts, save that the CAF will produce written decisions, which will be made public. However, at the time of writing it is not entirely clear how the overlapping performance of the CAF and the CVM will work in practice.

\section{Conclusion}

We have seen that four distinct strategies for institutional development are being employed in Brazilian corporate and securities law to overcome the problem of the inefficacy of state courts in resolving business disputes: arbitration, specialist judicial chambers within the regular state courts, administrative enforcement by the CVM and, most recently, the establishment of the self-regulatory CAF. Each of these developments can be seen as a 'layer' based on the foundation of the basic system of corporate law enforced through state courts. Each derives its 'legality' to some extent from the underlying foundations. Yet each offers a way of overcoming some of the limitations of the underlying system. None is able completely to transcend these limitations, and so each is, by itself, an incomplete solution. However, the

${ }^{105}$ CVM/CAF Cooperation Agreement of 27 August 2013 (cafbrasil.org.br/site/en/normative-ruling/cooperationagreement/).

${ }^{106}$ CAF Code, Art 136, § 2. 
fact that all four approaches can be pursued simultaneously means that they overlap to a significant degree, especially in relation to areas crucial for facilitating outside investment such as the control of tunnelling by majority shareholders. None, individually, could be described as an ideal or fully functional enforcement mechanism. Yet collectively, they are mutually reinforcing, and their operation together is greater than the sum of their parts.

We consider that the account of institutional layering in Brazil offers insights that may usefully generalize to other emerging markets. Weak enforcement is an endemic problem for building legal institutions in emerging markets. The Brazilian approach suggests a focus on the art of the possible. Simultaneously pursuing whatever solutions that can be implemented, despite manifest limitations, may be more effective in aggregate than trying to pursue a single optimal solution which fails to get executed. 